\title{
Convenient preparation of high molecular weight poly(dimethylsiloxane) using thermally latent NHC-catalysis: a structure-activity correlation
}

\author{
Stefan Naumann ${ }^{1}$, Johannes Klein ${ }^{2}$, Dongren Wang ${ }^{1}$ and Michael R. Buchmeiser ${ }^{* 1,3}$
}

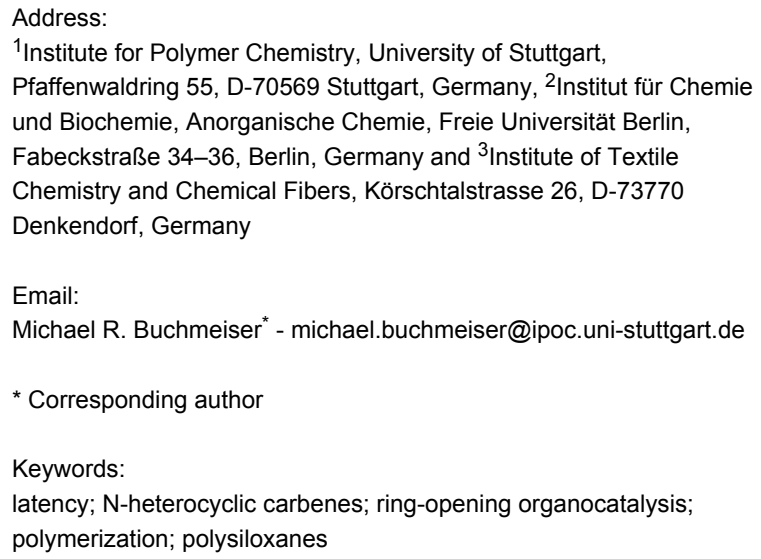

Beilstein J. Org. Chem. 2015, 11, 2261-2266. doi:10.3762/bjoc. 11.246

Received: 25 September 2015

Accepted: 04 November 2015

Published: 20 November 2015

This article is part of the Thematic Series "N-Heterocyclic carbenes".

Guest Editor: S. P. Nolan

(C) 2015 Naumann et al; licensee Beilstein-Institut. License and terms: see end of document.

\begin{abstract}
The polymerization of octamethylcyclotetrasiloxane $\left(\mathrm{D}_{4}\right)$ is investigated using several five-, six- and seven-membered $N$-heterocyclic carbenes (NHCs). The catalysts are delivered in situ from thermally susceptible $\mathrm{CO}_{2}$ adducts. It is demonstrated that the polymerization can be triggered from a latent state by mild heating, using the highly nucleophilic 1,3,4,5-tetramethylimidazol-2ylidene as organocatalyst. This way, high molecular weight PDMS is prepared (up to $>400000 \mathrm{~g} / \mathrm{mol}, 1.6<\bigoplus_{\mathrm{M}}<2.5$ ) in yields $>95 \%$, using low catalyst loadings $(0.2-0.1 \mathrm{~mol} \%)$. Furthermore, the results suggest that a nucleophilic, zwitterionic mechanism is in operation, in preference to purely anionic polymerization.
\end{abstract}

\section{Introduction}

N-Heterocyclic carbenes (NHCs) [1-3] have had a resounding impact on organopolymerization [4,5] during the past fifteen years. Considerable research effort has steadily deepened the mechanistic understanding of the polymerization pathways open to NHCs, while the range of accessible monomer structures has grown impressively [6,7]. Nowadays, NHC-mediated polymerization can be applied to prepare polymers of high industrial and commercial importance, such as poly(amide)s [8,9], poly(ether)s [10], poly(urethane)s [11,12] or poly(acrylate)s [13-18]. Likewise, poly(siloxane)s are attractive and versatile macromolecular materials produced on large scale and thus a rewarding field for the development of new catalysts, the more so if the added benefit of metal-free conditions can be implemented [19-21]. In spite of this, few investigations regarding the performance of NHCs in this area have been published. In 2006, Waymouth, Hedrick and co-workers showed that 
poly(carbosiloxane)s can be synthesized efficiently from the monomer 2,2,5,5-tetramethyl-1-oxa-2,5-disilacyclopentane in the presence of alcohols as initiators, using two different NHCs [22]. Control over the molecular weight was good $\left(\bigoplus_{M}<1.2\right)$, but prolonged polymerization led to transetherification. Interestingly, the formation of high molecular weight cyclic poly(carbosiloxane) was observed in the absence of an initiator [23]. Additionally, octamethylcyclotetrasiloxane $\left(D_{4}\right)$ was used to prepare poly(dimethylsiloxane) (PDMS), using three different imidazolium-based free NHCs in combination with benzyl alcohol or methanol as initiator [24]. There, polymerizations were conducted at $80{ }^{\circ} \mathrm{C}$ for $16 \mathrm{~h}$ to achieve conversions of about $85 \%\left(1.5<\bigoplus_{\mathrm{M}}<1.7,0.1 \%\right.$ catalyst loading $)$. Notably, it was found that steric hindrance of the NHC shut down polymerization activity. Finally, a report on the polycondensation of $\alpha, \omega$-disilanols describes the efficient polycondensation via NHCs in spite of the generation of water during the reaction, finding that the most basic NHC in the small study delivered the best results [25]. In view of these promising, yet somewhat limited, results, the aim for this study was (a) to investigate a range of structurally diverse NHCs to get more insight into the influence of NHC structure on catalytic activity for the polymerization of $\mathrm{D}_{4}$, and (b) to generate the NHCs in situ from thermally labile $\mathrm{CO}_{2}$ adducts. This type of NHC delivery offers the double advantage of improved stability and storability of the NHC adduct and the possibility to generate "on demand" polymerization systems where the catalyst can be activated by heating. This way, a latent, easy-to-handle metal-free process which is more competitive in comparison with other catalytic systems can be realized [26].

\section{Results and Discussion}

Several five-, six- and seven-membered NHCs were prepared and reacted with carbon dioxide to receive the corresponding $\mathrm{CO}_{2}$ adducts (Scheme 1, top), following literature procedures (see Supporting Information File 1). Compounds 7-Neo-CO $\mathbf{O}_{2}$, 7-iPr- $\mathrm{CO}_{2}$ and $\mathbf{5}_{\mathbf{C l}}-\mathrm{Me}-\mathrm{CO}_{2}$ have not been described before and full characterization can be found in the experimental part (Supporting Information File 1). In accordance with previous findings [17,27], these NHC-carboxylates were stable at room temperature over long periods of time (observed for up to 2 years) without decomposition, exclusion of humidity provided.

Polymerization experiments with $\mathrm{D}_{4}$ were conducted solventfree at elevated temperature $\left(80^{\circ} \mathrm{C}, 16 \mathrm{~h}\right)$, both in presence and absence of an initiator (benzyl alcohol, BnOH). This immediately revealed sharp differences of reactivity between the individual pre-catalysts (Table 1). When the protected NHC was applied in conjunction with $\mathrm{BnOH}$, only $\mathbf{5}_{\mathbf{M e}}-\mathbf{M e}-\mathbf{C O} \mathbf{O}_{\mathbf{2}}$ showed relevant activity, albeit a very high one.

At a catalyst loading of only $0.2 \mathrm{~mol} \%$, a molecular weight $\left(M_{\mathrm{n}}\right)$ of $70000 \mathrm{~g} / \mathrm{mol}$ was achieved at $94 \%$ monomer conver-<smiles></smiles> 


\begin{tabular}{|c|c|c|c|c|c|}
\hline Entry & $\mathrm{NHC}-\mathrm{CO}_{2}$ & $\mathrm{NHC/BnOH/D4}$ & Conversion [\%] ${ }^{\mathrm{a}}$ & $M_{\mathrm{n}} \times 10^{3}[\mathrm{~g} / \mathrm{mol}]^{\mathrm{b}}$ & $\oplus_{\mathrm{M}}$ \\
\hline 1 & $5_{\mathrm{Me}}-\mathrm{Me}-\mathrm{CO}_{2}$ & $1: 5: 500$ & 94 & 70 & 1.7 \\
\hline 2 & $5_{\mathrm{Me}}-\mathrm{Me}-\mathrm{CO}_{2}$ & 1:1:100 & $>95$ & 198 & 1.9 \\
\hline 3 & $5_{\mathrm{Me}}-\mathrm{Me}-\mathrm{CO}_{2}$ & 1:1:300 & $>95$ & 288 & 1.9 \\
\hline 4 & $5_{\mathrm{Me}}-\mathrm{Me}-\mathrm{CO}_{2}$ & $1: 1: 700$ & $>95$ & 360 & 2.5 \\
\hline 5 & $5_{\mathrm{Me}-\mathrm{Me}-\mathrm{CO}_{2}}$ & 1:1:1000 & $>95$ & 424 & 2.2 \\
\hline 6 & 5-Mes- $\mathrm{CO}_{2}$ & $1: 5: 500$ & 7 & - & - \\
\hline 7 & $5_{\mathrm{Cl}}-\mathrm{Me}-\mathrm{CO}_{2}$ & $1: 5: 500$ & 0 & - & - \\
\hline 8 & 6-iPr- $\mathrm{CO}_{2}$ & $1: 5: 500$ & 0 & - & - \\
\hline 9 & 6-Cy-CO & $1: 5: 500$ & 0 & - & - \\
\hline 10 & 7-iPr-CO & $1: 5: 500$ & 5 & - & - \\
\hline 11 & 7-Neo-CO & $1: 5: 500$ & 0 & - & - \\
\hline 12 & $5_{\mathrm{Me}}-\mathrm{Me}-\mathrm{CO}_{2}$ & 1:0:100 & 92 & 8 & 1.3 \\
\hline 13 & 6-Cy-CO & 1:0:100 & insoluble & n. d. & - \\
\hline 14 & 7-iPr-CO & 1:0:100 & insoluble & n. d. & - \\
\hline
\end{tabular}

aDetermined by ${ }^{1} \mathrm{H}$ NMR spectroscopy; ${ }^{\mathrm{b}}$ via GPC (THF, PS standards).

sion. Interestingly, some degree of control over the molecular weight is possible by adjusting the initiator to monomer ratio (Table 1, entries 2-5). This way, up to a target degree of polymerization (DP) of 1000, considerable molecular weight can be built up, ranging from $200000 \mathrm{~g} / \mathrm{mol}$ to over $400000 \mathrm{~g} / \mathrm{mol}$ $\left(M_{\mathrm{n}}\right)$. Importantly, in all these cases very high conversion is observed. Matrix-assisted laser desorption/ionization time-offlight mass spectrometry (MALDI-ToF MS) and NMR experiments clearly show that $\mathrm{BnOH}$ is incorporated in the resulting PDMS (S1-S3), underlining the defined structure of the polymer. Contrasting this behaviour of $\mathbf{5}_{\mathbf{M e}}-\mathbf{M e}-\mathbf{C O}_{2}$, its sterically more hindered analogue, 5-Mes- $\mathrm{CO}_{2}$, only brought about a low conversion of $7 \%$ under identical conditions (Table 1 , entry 6), while its electron-poor derivative $\mathbf{5}_{\mathbf{C l}}-\mathbf{M e}-\mathbf{C O} \mathbf{O}_{2}$ was completely inactive (Table 1, entry 7). More surprisingly, the six- and seven-membered pre-catalysts were all found to deliver very little or no polymer. Differently, in the absence of $\mathrm{BnOH}$ (1\% catalyst loading, Table 1, entries 12-14), application of both 7-iPr- $-\mathbf{C O}_{2}$ and 6-Cy-CO $\mathbf{C O}_{2}$ resulted in an insoluble polymer, most probably because very high molecular weight was generated. Gratifyingly, under the same parameters $\mathbf{5}_{\mathbf{M e}} \mathbf{M}^{-}$ Me- $\mathrm{CO}_{2}$ effected a conversion of $92 \%\left(M_{\mathrm{n}}=8100 \mathrm{~g} / \mathrm{mol}\right)$. Overall, polymerization with this pre-catalyst proceeds noticeably faster in the presence than in the absence of an initiator (Figure 1). At a polymerization setup of $\mathrm{NHC} / \mathrm{BnOH} / \mathrm{D}_{4}=$ $1: 5: 500$, the conversion is practically complete after only $2.5 \mathrm{~h}$.

Above findings obviously render $\mathbf{5}_{\mathbf{M e}}-\mathbf{M e}-\mathbf{C O} \mathbf{O}_{2}$ the most suitable pre-catalyst, but important conclusions with regard to the polymerization mechanism can also be drawn. In part, the results nicely mirror findings by Baceiredo and co-workers [24], who described that steric hindrance eliminates any poly-

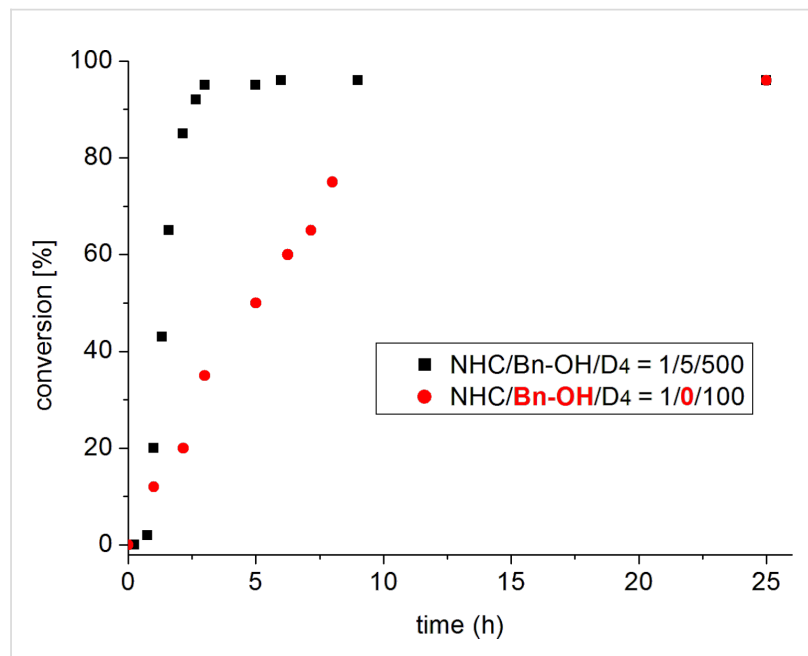

Figure 1: Comparison of conversion over time for $\mathrm{D}_{4}$ polymerization $\left(80^{\circ} \mathrm{C}\right.$, bulk) using $5_{\mathrm{Me}}-\mathbf{M e}-\mathrm{CO}_{2}$. Note that the fivefold monomer excess was used in case of $\mathrm{BnOH}$ being present.

merization activity of the $\mathrm{NHC}$; the same is found here when comparing the performance of $\mathbf{5}_{\mathbf{M e}}-\mathbf{M e}-\mathbf{C O}_{2}$ and 5-Mes-CO $\mathbf{C O}_{2}$. Additionally, electron-withdrawing substituents (as present in $\mathbf{5}_{\mathbf{C l}}-\mathbf{M e}-\mathbf{C O}_{2}$ ) preclude any activity, emphasizing that nucleophilicity is crucial for successful polymerization. Furthermore, it is interesting to note that the six- and seven-membered NHCs do not show any reactivity here, in spite of being very strong bases. While for a compound like 6-iPr a pKa-value of 28.2 (aqueous solution, $25{ }^{\circ} \mathrm{C}$ ) was found, the five-membered imidazolium derivative 5-Mes was determined to have a $\mathrm{pKa}$-value of only 20.8 (which compares to 15-19 for typical alcohols; in turn, silanols are even more acidic than the corresponding alcohols) [28-32]. 
At the same time, $\mathbf{5}_{\mathbf{M e}}-\mathbf{M e}-\mathbf{C O} \mathbf{O}_{\mathbf{2}}$ successfully catalyzed PDMSformation in the absence of $\mathrm{BnOH}$ (see above), and hence a mechanism for direct $\mathrm{D}_{4}$ polymerization must exist.

Taken together, all above points strongly suggest that nucleophilic ring-opening of the monomer by the NHC is the key step, in agreement with previous proposals [24]. A purely basic (anionic) pathway (Scheme 2), often preferred by the sixmembered NHCs [7-9,17], seems clearly disfavoured. In the absence of $\mathrm{BnOH}$, it is therefore reasonable to assume zwitterionic propagation, in analogy to recent findings for NHC-mediated lactone polymerization [33]. The insoluble material received by the action of 7-iPr- $\mathbf{C O}_{2}$ and $\mathbf{6 - C y}-\mathbf{C O}_{2}$ could be connected to a low initiation efficiency and consequently low ratio of propagating zwitterions to monomer, resulting in highmolecular weight polymers. In contrast, a sterically uncongested, highly nucleophilic NHC as liberated from $\mathbf{5}_{\mathbf{M e}}-\mathbf{M e}-$ $\mathrm{CO}_{2}$ (Table 1, entry 12) is more suitable under these conditions.

Finally, a mixture of $\mathbf{5}_{\mathbf{M e}}-\mathrm{Me}-\mathrm{CO}_{\mathbf{2}}, \mathrm{BnOH}$ and $\mathrm{D}_{4}$ was tested for thermal latency (Figure 2). Notably, after $72 \mathrm{~h}$ at a slightly elevated temperature of $45{ }^{\circ} \mathrm{C}$ only negligible conversion was observed. A relatively mild increase to $80^{\circ} \mathrm{C}$, however, triggered a clean jump to near quantitative conversion. Hence, with this catalytic setup it is possible to form one-component, metal- free mixtures which can be activated by mild heating. Polymerization of $\mathrm{D}_{4}$ is entropically driven $[21,34]$ and thus profits from elevated temperature in any case, rendering the implementation of thermally labile pre-catalysts both practically feasible and advantageous.

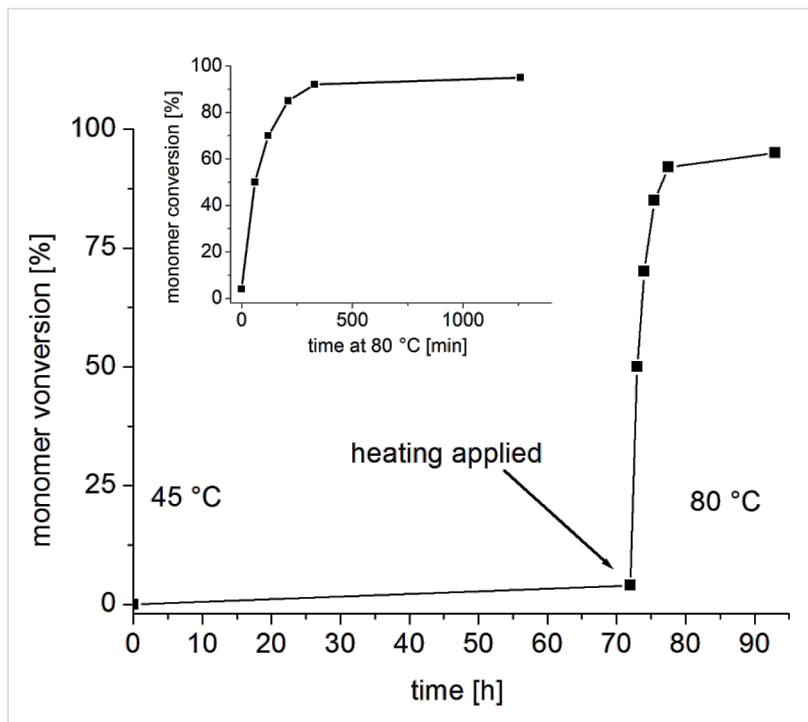

Figure 2: Thermal activation of a $5_{\mathrm{Me}}-\mathrm{Me}-\mathrm{CO}_{2} / \mathrm{BnOH} / \mathrm{D}_{4}(1: 5: 500)$ composition after a latency period of $72 \mathrm{~h}$.

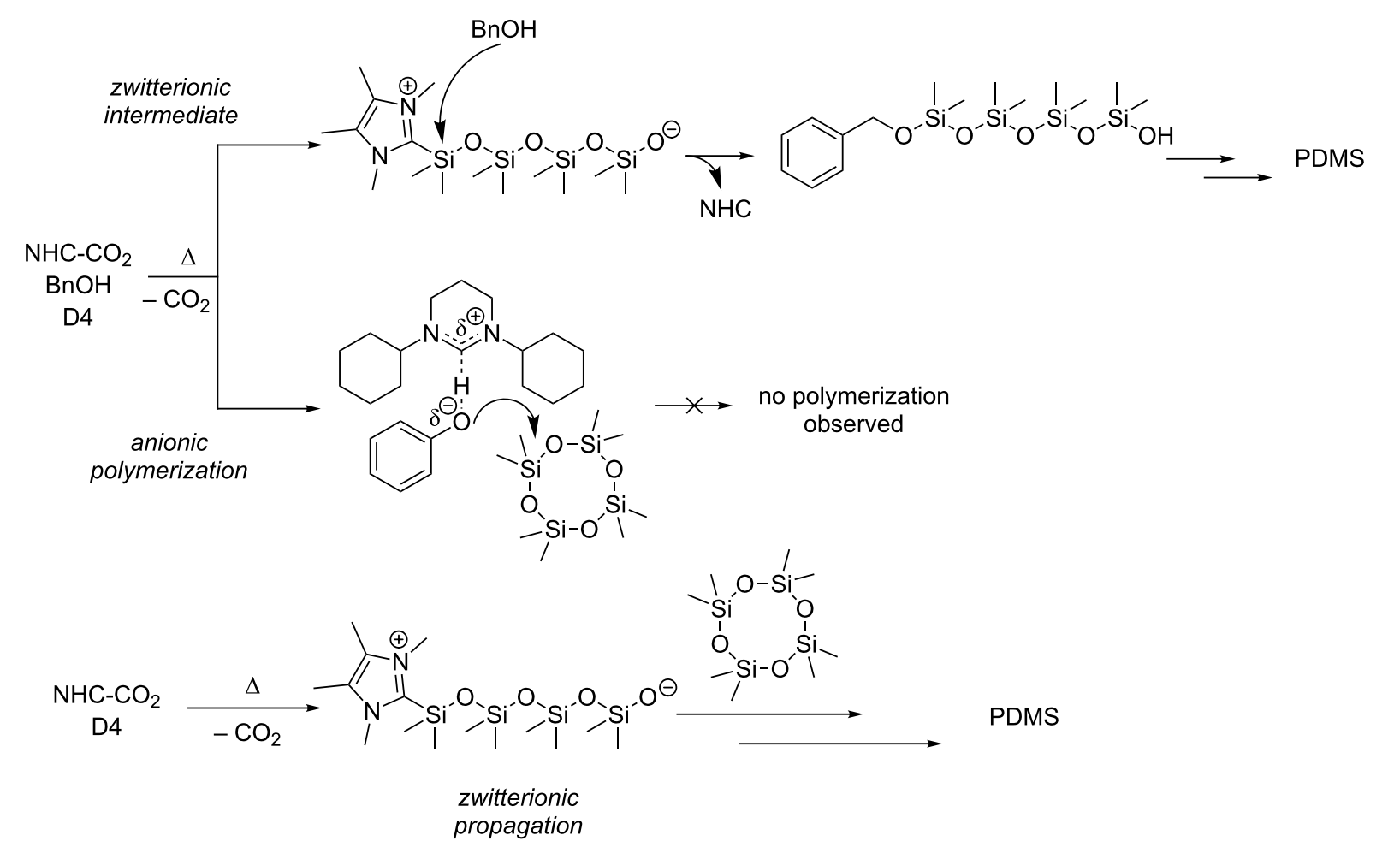




\section{Conclusion}

In conclusion, we have demonstrated the first polymerization of $\mathrm{D}_{4}$ using NHC-carboxylates. Sterically non-hindered, highly nucleophilic protected NHCs like $\mathbf{5}_{\mathbf{M e}}-\mathbf{M e}-\mathbf{C O}_{\mathbf{2}}$ offer access to an "on demand", metal-free and effective preparation of PDMS, including high molecular weight polymers. The results of a screening of a range of different NHCs indicate that a nucleophilic action of the organocatalyst is preferred over action as a Brønsted base.

\section{Supporting Information}

\section{Supporting Information File 1}

Details on the synthesis of $\mathrm{NHC}-\mathrm{CO}_{2}$ and polymerizations.

[http://www.beilstein-journals.org/bjoc/content/ supplementary/1860-5397-11-246-S1.pdf]

\section{Acknowledgements}

The authors SN, JK and DW all contributed equally to the preparation of the manuscript. M. Sc. Suman Sen is acknowledged for synthetic support.

\section{References}

1. Hahn, F. E.; Jahnke, M. C. Angew. Chem., Int. Ed. 2008, 47, 3122-3172. doi:10.1002/anie.200703883

2. Dröge, T.; Glorius, F. Angew. Chem., Int. Ed. 2010, 49, 6940-6952. doi:10.1002/anie.201001865

3. Hopkinson, M. N.; Richter, C.; Schedler, M.; Glorius, F. Nature 2014, 510, 485-496. doi:10.1038/nature13384

4. Kiesewetter, M. K.; Shin, E. J.; Hedrick, J. L.; Waymouth, R. M. Macromolecules 2010, 43, 2093-2107. doi:10.1021/ma9025948

5. Dove, A. P. ACS Macro Lett. 2012, 1, 1409-1412. doi:10.1021/mz3005956

6. Fèvre, M.; Pinaud, J.; Gnanou, Y.; Vignolle, J.; Taton, D. Chem. Soc. Rev. 2013, 42, 2142-2172. doi:10.1039/c2cs35383k

7. Naumann, S.; Dove, A. P. Polym. Chem. 2015, 6, 3185-3200. doi:10.1039/C5PY00145E

8. Naumann, S.; Epple, S.; Bonten, C.; Buchmeiser, M. R. ACS Macro Lett. 2013, 2, 609-612. doi:10.1021/mz400199y

9. Naumann, S.; Schmidt, F. G.; Speiser, M.; Böhl, M.; Epple, S.; Bonten, C.; Buchmeiser, M. R. Macromolecules 2013, 46, 8426-8433. doi: $10.1021 / \mathrm{ma} 4018586$

10. Raynaud, J.; Absalon, C.; Gnanou, Y.; Taton, D. J. Am. Chem. Soc. 2009, 131, 3201-3209. doi:10.1021/ja809246f

11. Bantu, B.; Pawar, G. M.; Decker, U.; Wurst, K.; Schmidt, A. M.; Buchmeiser, M. R. Chem. - Eur. J. 2009, 15, 3103-3109. doi:10.1002/chem.200802670

12. Coutelier, O.; El Ezzi, M.; Destarac, M.; Bonnette, F.; Kato, T.; Baceiredo, A.; Sivasankarapillai, G.; Gnanou, Y.; Taton, D. Polym. Chem. 2012, 3, 605-608. doi:10.1039/c2py00477a

13. Scholten, M. D.; Hedrick, J. L.; Waymouth, R. M. Macromolecules 2008, 41, 7399-7404. doi:10.1021/ma801281q
14. Raynaud, J.; Ciolino, A.; Baceiredo, A.; Destarac, M.; Bonnette, F.; Kato, T.; Gnanou, Y.; Taton, D. Angew. Chem., Int. Ed. 2008, 47, 5390-5393. doi:10.1002/anie.200800490

15. Zhang, Y.; Chen, E. Y.-X. Angew. Chem., Int. Ed. 2012, 51, 2465-2469. doi:10.1002/anie.201108019

16. Hong, M.; Chen, E. Y.-X. Angew. Chem., Int. Ed. 2014, 53, 11900-11906. doi:10.1002/anie.201406630

17. Naumann, S.; Schmidt, F. G.; Schowner, R.; Frey, W.; Buchmeiser, M. R. Polym. Chem. 2013, 4, 2731-2740. doi:10.1039/c3py00073g

18. Matsuoka, S.-i.; Namera, S.; Suzuki, M. Polym. Chem. 2015, 6, 294-301. doi:10.1039/C4PY01184H

19. Manners, I. Angew. Chem., Int. Ed. Engl. 1996, 35, 1602-1621. doi:10.1002/anie.199616021

20. Chojnowski, J. J. Inorg. Organomet. Polym. 1991, 1, $299-323$. doi:10.1007/BF00702495

21. Mark, J. E.; Schaefer, D. W.; Lin, G. The polysiloxanes; Oxford University Press: New York, NY, 2015.

22. Lohmeijer, B. G. G.; Dubois, G.; Leibfarth, F.; Pratt, R. C.; Nederberg, F.; Nelson, A.; Waymouth, R. M.; Wade, C.; Hedrick, J. L. Org. Lett. 2006, 8, 4683-4686. doi:10.1021/ol0614166

23. Brown, H. A.; Chang, Y. A.; Waymouth, R. M. J. Am. Chem. Soc. 2013, 135, 18738-18741. doi:10.1021/ja409843v

24. Rodriguez, M.; Marrot, S.; Kato, T.; Stérin, S.; Fleury, E.; Baceiredo, A. J. Organomet. Chem. 2007, 692, 705-708. doi:10.1016/j.jorganchem.2006.10.006

25. Marrot, S.; Bonnette, F.; Kato, T.; Saint-Jalmes, L.; Fleury, E.; Baceiredo, A. J. Organomet. Chem. 2008, 693, 1729-1732. doi:10.1016/j.jorganchem.2008.02.011

26. Naumann, S.; Buchmeiser, M. R. Catal. Sci. Technol. 2014, 4, 2466-2479. doi:10.1039/c4cy00344f

27. Van Ausdall, B. R.; Glass, J. L.; Wiggins, K. M.; Aarif, A. M.; Louie, J. J. Org. Chem. 2009, 74, 7935-7942. doi:10.1021/jo901791k

28. Higgins, E. M.; Sherwood, J. A.; Lindsay, A. G.; Armstrong, J.; Massey, R. S.; Alder, R. W.; O'Donoghue, A. C. Chem. Commun. 2011, 47, 1559-1561. doi:10.1039/C0CC03367G

29. Magill, A. M.; Cavell, K. J.; Yates, B. F. J. Am. Chem. Soc. 2004, 126, 8717-8724. doi:10.1021/ja038973x

30. Kim, Y.-J.; Streitwieser, A. J. Am. Chem. Soc. 2002, 124, 5757-5761. doi:10.1021/ja025628j

31. Brown, W. H.; Foote, C. S.; Iverson, B. L.; Anslyn, E. V. Organic chemistry, 6th ed.; Brooks/Cole, Cengage Learning: Belmont, CA, 2012.

32. Chandrasekhar, V.; Boomishankar, R.; Nagendran, S. Chem. Rev. 2004, 104, 5847-5910. doi:10.1021/cr0306135

33. Brown, H. A.; Waymouth, R. M. Acc. Chem. Res. 2013, 46, 2585-2596. doi:10.1021/ar400072z

34. Odian, G. Principles of Polymerization, 4th ed.; John Wiley \& Sons: Hoboken, 2004. doi:10.1002/047147875X 


\section{License and Terms}

This is an Open Access article under the terms of the Creative Commons Attribution License

(http://creativecommons.org/licenses/by/2.0), which permits unrestricted use, distribution, and reproduction in any medium, provided the original work is properly cited.

The license is subject to the Beilstein Journal of Organic Chemistry terms and conditions:

(http://www.beilstein-journals.org/bjoc)

The definitive version of this article is the electronic one which can be found at:

doi:10.3762/bjoc.11.246 